served and a term like Alexandrian series be established as a valid stratigraphic title.

Charles Keyes

\section{ALABAMA ARGILLACEA IN MINNESOTA}

The cotton-worm moth, Alabama argillacea Hubn., appeared in Minnesota during the past season at several different places. The first recorded appearance was at Garden City, Blue Earth County, September 21, where it was proving injurious to a variety of everbearing strawberries. The moths punctured the fruit and apparently did considerable injury.

Between the tenth and the fifteenth of October, several other inquiries from other places were received, complaining of this moth injuring strawberries. One complaint came from Rochester, Minn., one from St. Paul, and one from Excelsior, which is on Lake Minnetonka, west of Minneapolis. The moths apparently stayed but a very short time in each of these places. Between the fifteenth and nineteenth of October the nurseryman at Garden City, Minn., had further trouble from these moths. $\mathrm{He}$ stated in a letter that they were most abundant about the twentieth of September, after which they disappeared, becoming rather scarce, but appearing again in numbers about the fifteenth of October.

These few notes may be of interest to entomologists, as they show the northern flight of the moths; also that they will feed on fruit, if fruit is available at that time.

William Moore

Division of Entomology, UNIVERSITt OF MINNESOTA

\section{OHEMIHYDROMETRY}

THE writer has been searching for a name for the new method of measuring the flow of rivers, the discharge of turbines and the capacities of reservoirs by means of chemicals mixed with liquids. Chemihydrometry seems to convey the idea exactly, but it can be criticized in at least two respects. It is a compound whose component parts are derived from two different languages, which is not good form, and the second part is almost exclusively used when it refers to the determination of density or specific gravity.
An appropriate name for this new branch of engineering will soon be in demand and it is, therefore, suggested that other names be submitted by your readers for consideration.

B. F. GroAT

EYE SHADES FOR MICROSCOPICAL WORK

To the Editor of Science: The eye shade described in Scrence for May 28 is identical in plan though not quite as perfect in construction as one sold for many years by dealers in microscopic supplies. It was designed by Dr. R. H. Ward and is illustrated in earlier editions of Gage, "The Microscope" (e. g., VI. ed., p. 59), and in various catalogues of micro accessories as Ward's Eye Shade. In the later editions of Professor Gage's book it is replaced by another form which in the author's judgment probably meets the needs of the case more satisfactorily.

The discussion which Professor Gage gives in connection with the figure of the eye shade regarding the care of the eyes is worthy the more careful consideration of the laboratory teacher. Such problems receive little, if any, attention in the training of graduate students, and college classes suffer when every new generation of teachers comes to practise on them.

X

\section{SCIENTIFIC BOOKS}

The Climatic Factor as illustrated in Arid North America. By ElLsworth HuntingTON, with contributions by CHARLES SOHUCHert, ANDrew E. Douglass and Charles J. Fullmer. Carnegie Institution of Washington, Publ. 192, 1914. 4to. Pp. 341, richly illustrated.

The senior author of "The Climatic Factor" has for a number of years endeavored to throw light upon the relations between changes in climate and human activity, and the wealth of fact which he personally has hitherto brought to light and correlated with the investigations of others, especially archeologists, in that region called the cradle of western civilization, together with interpretation in terms of climatic oscillation, have won for him much recognition both from a wide circle of the 